\title{
FORMULASI EKSTRAK ETANOL DAUN SIRIH HIJAU (Piper betle Linn.) SEBAGAI GEL HAND SANITIZER
}

\author{
Zulfikri $^{*}$, Cici Dianti ${ }^{2}$ \\ ${ }^{1,2}$ Universitas Haji Sumatera Utara, Medan, Indonesia \\ Email : fikroa@gmail.com \\ *Corresponding author
}

\begin{abstract}
Abstrak
Kesehatan merupakan salah astu aspek penting yang dapat berpengaruh pada kehidupan setiap orang. Salah satu cara yang cukup efektif dalam menjaga kesehatan tubuh yaitu dengan menjaga kebersihan seperti kebersihan tangan. Tangan dapat menjadi jalur penularan berbagai penyakit menular seperti gangguan usus dan pencernaan (diare dan muntah) dan berbagai penyakit lain. Salah satu cara praktis dalam pencegahan penyakit dapat dilakukan dengan menggunakan hand sanitizer untuk mengganti cuci tangan. Metode dalam penelitian ini menggunakan eksperimental. Penelitian ini meliputi, pembuatan orientasi basis gel, menformulasikan ekstrak etanol daun sirih hijau 5\%, 10\%, 15\%, dan 20\% dalam sediaan gel hand sanitizer, uji evaluasi sediaan meliputi organoleptis, homogenitas, $\mathrm{pH}$, daya sebar, uji stabilitas, dan iritasi pada kulit. Hasil penelitian menunjukkan esktrak etanol daun sirih hijau (Piper betle Linn.) dapat diformulasikan dalam bentuk sediaan gel hand sanitizer dan stabil baik fisik sediaan, homogenitas, $\mathrm{pH}$, daya sebar sediaan serta tidak menimbulkan iritasi kulit. Uji organoleptik pada sediaan diperoleh pada semua F0 memiliki warna putih sedangkan pada formula 1 sampai 4 memiliki warna kuning kehijauan, pada uji homogenitas diperoleh hasil homogen untuk semua formula, pada uji $\mathrm{pH}$ diperoleh nilai pH berkisar antara 4-5, pada uji daya sebardiperoleh hasil pada F0 (Blanko) yaitu $6 \mathrm{~cm}$, pada F1 (5\%) yaitu $6,5 \mathrm{~cm}$, pada $\mathrm{F} 3(15 \%)$ yaitu $6,5 \mathrm{~cm}$ dan pada $\mathrm{F} 4(20 \%)$ yaitu $5,5 \mathrm{~cm}$, untuk uji stabilitas yaitu stabil, uji iritasi yaitu tidak menyebabkan iritasi pada kulit.
\end{abstract}

Kata Kunci: Formulasi, Sediaan Gel, Hand Sanitizer, Daun Sirih Hijau.

\begin{abstract}
Health is an important aspect that can affect everyone's life. The one of effective ways to maintain a healthy body is to maintain cleanliness, namely hand hygiene. Hands are one of the routes of transmission of various infectious diseases such as intestinal and digestive disorders such as (diarrhea and vomiting) and various other diseases. One practical way to prevent disease can be done by using a hand sanitizer instead of washing hands. The method in this research is experimental. This research includes, making orientation of gel base, formulating ethanol extract of betel leaf $5 \%, 10 \%, 15 \%$, and $20 \%$ in hand sanitizer gel preparations, preparation evaluation tests include organoleptic, homogeneity, pH, dispersibility, stability test, and skin irritation. The results showed that the ethanol extract of green betel leaf (Piper betle Linn.) can be formulated in the form of a hand sanitizer gel and is stable in terms of physical preparation, homogeneity, $\mathrm{pH}$, dispersion of the preparation and does not cause skin irritation. The organoleptic test on the preparations obtained on all FO has a white color while in formulas 1 to 4 it has a greenish yellow color, the homogeneity test obtained homogeneous results for all formulas, the pH test obtained pH values ranging from 4-5, in the dispersion test the results were obtained at FO (Blank) is $6 \mathrm{~cm}$,
\end{abstract}


at F1 (5\%) is $6.5 \mathrm{~cm}$, at F3 (15\%) is $6.5 \mathrm{~cm}$ and at F4 (20\%) is $5.5 \mathrm{~cm}$, for the stability test it is stable, for irritation test that is not irritating to the skin.

Keywords: Formulation, Gel Preparation, Hand Sanitizer, Green Betel leaf

\section{PENDAHULUAN}

Kesehatan merupakan aspek penting yang dapat mempengaruhi kehidupan setiap orang. Salah satu cara yang cukup efektif dalam menjaga kesehatan tubuh yaitu dengan menjaga kebersihan seperti kebersihan tangan (Radji, 2010). Tangan merupakan anggota tubuh yang berperan penting dalam aktivitas sehari-hari (Radji, 2010). Tangan juga menjadi salah satu jalur penularan berbagai penyakit menular seperti gangguan usus dan pencernaan (diare dan muntah) dan juga berbagai penyakit lainnya. Namun, kesadaran masyarakat Indonesia terhadap pentingnya membersihkan tangan masih sangat kurang.

Daun sirih hijau mengandung senyawa metabolit sekunder yaitu minyak atsiri, alkaloid, flavonoid, fenolik, dan tannin. Dimana tanaman yang mengandung flavonoid berfungsi sebagai antibakteri dan saponin sebagai antimikroba yang mampu berperan dalam menyembuhkan atau memperbaiki kondisi kesehatan masyarakat (Moeljanto dan Mulyono, 2003). Hand sanitizer merupakan gel dengan berbagai kandungan yang berfungsi membunuh mikroorganisme dikulit tangan. Hand sanitizer sering dimanfaatkan karena alasan lebih praktis dan mudah dibawa serta dapat digunakan tanpa menggunakan air. Cara penggunaannya dengan meneteskan pada telapak tangan, lalu diratakan pada seluruh permukaan tangan. Salah satu kelebihan hand sanitizer menurut FDA (Food and Drug Administration) yaitu dengan cepat membunuh kuman dalam waktu singkat. Antiseptik dalam berbagai bentuk sediaan merupakan faktor pendukung masyarakat dalam menggunakan hand sanitizer (Hurria, 2014).

Kandungan bahan aktif yang ada dalam hand sanitizer seperti etanol, propanol, isopropanol (golongan alkohol) mencapai konsentrasi $\pm 50 \%-70 \%$, klorheksidin dan triklosan. Alkohol sangat efektiv terhadap virus, bakteri, dan juga jamur serta tidak menimbulkan resistensi pada bakteri. Namun penggunaan alkohol dapat memberikan efek tangan menjadi kering, sehingga hand sanitizer perlu ditambah dengan moisturizer dan emolient, berfungsi menjaga tangan tetap lembut dan tidak kering, dan tidak seperti cairan alkohol murni yang dapat menyebabkan dehidrasi pada kulit.

\section{METODE PENELITIAN}

Pada penelitian ini menggunakan metode eksperimental (Experiment Research). Penelitian dilakukan di Laboratorium Farmasi Universitas Haji Sumatera Utara Medan. Sampel yang digunakan adalah daun sirih hijau (Piper betle Linn.) yang didapat dari desa Air Joman Kabupaten Asahan Provinsi Sumatera Utara. Metode eksperimental yang dilakukan meliputi pembuatan formulasi gel hand sanitizer dari ektstrak daun sirih hijau (Piper betle Linn.) dengan konsentrasi Blanko : 0\%, F1:5\%, F2:10\%, F3:15\%, F4: $20 \%$.

\section{Alat dan Bahan}

a. Alat

Alat yang digunakan yaitu timbangan, blender, kertas saring, erlenmeyer, batang pengaduk, gelas ukur, waterbath, lumpang dan alu, pot sediaan gel, $\mathrm{pH}$ meter, pipet tetes, cawan porselin, toples kaca, corong. 


\section{b.Bahan}

Bahan-bahan yang digunakan yaitu daun sirih hijau (Piper betle Linn), carbopol, gliserin, Propilen glikol (Propylenglycolum), Trietanolamin (TEA), alkohol 70\%, Propil Paraben, Metil Paraben, Aquades.

\section{Ekstraksi}

Sampel daun sirih hijau (Piper betle Linn.) diekstraksi dengan menggunakan etanol 70\%. Pembuatan ekstrak dilakukan dengan metode maserasi, yaitu sebanyak 500 gram serbuk simplisia dimasukkan kedalam bejana maserat, tuangi dengan $3750 \mathrm{ml}$ bagian etanol, ditutup, biarkan selama 5 (lima) hari terlindungi dari cahaya sinar matahari, sambil sekali-kali diaduk. Setelah 5 hari campuran tersebut diserkai, diperas dan dibilas ampasnya dengan menggunakan sisa cairan penyari sebanyak $1250 \mathrm{ml}$, kemudian maserat dibiarkan selama 2 (dua) hari, lalu di enaptuangkan. Maserat kemudian diuapkan dengan alat penguap yaitu Rotary evaporator pada suhu tidak lebih dari $50^{\circ} \mathrm{C}$ dengan tujuan untuk menghilangkan pelarut etanol pada ekstrak. Ekstrak kental yang diperoleh ditimbang (Depkes RI, 2000).

\section{Skrining Fitokimia \\ Pemeriksaan Alkaloid}

Sebanyak 0,5 g ekstrak ditambah $1 \mathrm{ml}$ asam klorida $2 \mathrm{~N}$ dan $9 \mathrm{ml}$ air suling. Panaskan di atas penangas air selama 2 menit, dinginkan lalu disaring. Hasil penyaringan berupa filtrat dibagi kedalam 3 tabung untuk uji alkaloid sebagai berikut :

a. Filtrat 3 tetes ditambah 2 tetes larutan pereaksi Mayer akan terbentuknya endapan menggumpal bewarna putih atau kuning.

b. Filtrat 3 tetes ditambah 2 tetes larutan pereaksi Bouchardat akan terbentuk endapan berwarna coklat sampai kehitaman.

c. Filtrat 3 tetes ditambah 2 tetes larutan pereaksi Dragendorf, terbentuk endapan bewarna merah atau jingga (Depkes RI, 1995).

\section{Pemeriksaan Tanin}

Sebanyak $0,5 \mathrm{~g}$ sampel ditambah dengan $10 \mathrm{ml}$ air suling saring, lalu filtratnya diencerkan menggunakan air suling sampai tidak berwarna. Filtrat yang diperoleh diambil sebanyak $2 \mathrm{ml}$, lalu ditambahkan 1-2 tetes pereaksi $\mathrm{FeCl}_{3}$, akan terbentuk warna biru atau hijau kehitaman yang menunjukkan adanya senyawa tanin (Marliana dkk, 2005).

\section{Pemeriksaan Flavonoid}

Ditimbang simplisia sebanyak $\pm 0,5 \mathrm{~g}$ lalu ditambahkan $20 \mathrm{ml}$ air panas, didihkan selama 10 menit lalu disaring dalam keadaan panas, kedalam $5 \mathrm{ml}$ filtrat tambahkan $0,1 \mathrm{~g}$ serbuk magnesium, $1 \mathrm{ml}$ asam klorida pekat dan $2 \mathrm{ml}$ amil alkohol, lalu dikocok dan dibiarkan memisah. Adanya senyawa flavonoid jika terbentuk warna merah kuning jingga pada lapisan amil alkohol (Marliana dkk, 2005).

\section{Pemeriksaan Polifenol}

Ekstrak simplisia sebanyak $0,1 \mathrm{~g}$ dimasukkan ke dalam tabung, kemudian ditambahkan beberapa tetes larutan $\mathrm{FeCl}_{3} 1 \%$. Senyawa kelompok fenol ditandai dengan munculnya warna hijau, merah, ungu atau hitam (Marliana dkk, 2005). 
Tabel 1. Formula sediaan gel hand sanitizer ekstrak daun sirih hijau (Piper betle Linn.)

\begin{tabular}{lccccc}
\multicolumn{1}{c}{ Bahan } & \multicolumn{5}{c}{ Konsentrasi (\%) } \\
\cline { 2 - 6 } & $\begin{array}{c}\text { Fo } \\
\text { (Blanko) }\end{array}$ & F1 & F2 & F3 & F4 \\
& & & & & \\
\hline $\begin{array}{l}\text { Ekstrak daun sirih } \\
\text { (Piper betle Linn.) }\end{array}$ & 0 & 5 & 10 & 15 & 20 \\
\hline Carbopol & 0,25 & 0,25 & 0,25 & 0,25 & 0,25 \\
\hline Gliserin & 2,5 & 2,5 & 2,5 & 2,5 & 2,5 \\
\hline TEA & 3,5 & 3,5 & 3,5 & 3,5 & 3,5 \\
\hline Etanol 70\% & 15 & 15 & 15 & 15 & 15 \\
\hline Metil paraben & 0,2 & 0,2 & 0,2 & 0,2 & 0,2 \\
\hline Propil paraben & 0,05 & 0,05 & 0,05 & 0,05 & 0,05 \\
\hline Parfum (esens lemon) & q.s & q.s & q.s & q.s & q.s \\
\hline Aquadest & ad 100 & ad 100 & ad 100 & ad 100 & ad 100 \\
\hline
\end{tabular}

\section{Keterangan:}

F0 : Basis gel hand sanitizer tanpa ekstrak daun sirih hijau (blanko)

F1 : Gel hand sanitizer ekstrak daun sirih hijau (Piper betle Linn.) 5\%

F2 : Gel hand sanitizer ekstrak daun sirih hijau (Piper betle Linn.) $10 \%$

F3 : Gel hand sanitizer ekstrak daun sirih hijau (Piper betle Linn.) $15 \%$

F4: Gel hand sanitizer ekstrak daun sirih hijau (Piper betle Linn.) 20\%

\section{Prosedur Kerja}

Disiapkan semua bahan kemudian di timbang semua bahan yang akan digunakan terlebih dahulu sesuai dengan formula. Dilarutkan carbopol dengan aquadest hingga larut dan mengembang sempurna. Kemudian TEA dilarutkan dengan sedikit aquadest lalu dimasukkan kedalam campuran carbopol, di aduk perlahan sampai terbentuk massa gel yang homogen (massa 1). Di cawan lainnya masukkan Gliserin, Propil Paraben dan Metil Paraben dilarutkan dengan aquadest panas sambil diaduk hingga semua bahan larut dan menyatu sempurna (massa 2). Dimasukkan masa I dan Masa II kedalam lumpang sambil digerus homogen dan sampai terbentuk basis gel. Dilarutkan Ekstrak daun sirih hijau (Piper betle Linn.) ke dalam beaker gelas dengan menggunakan etanol 70\% sedikit demi sedikit, kemudian di masukkan ke dalam lumpang yang berisi basis gel, di gerus hingga tercampur merata. Ditambahkan parfum sebanyak 2-3 tetes, kemudian masukkan sisa alkohol $70 \%$ dan sisa aquadest sampai sediaan $100 \mathrm{ml}$ sambil digerus hingga terbentuk sediaan gel hand sanitizer ekstrak daun sirih hijau (Piper betle Linn.) yang stabil dan mudah di aplikasikan ke tangan.

\section{HASIL DAN PEMBAHASAN}

\section{Skrining Fitokimia}

Tabel.1 Hasil Skrining fitokimia

\begin{tabular}{cc}
\hline Uji Fitokimia & Hasil \\
\hline Uji Tanin & $(+)$ Tanin \\
\hline Uji flavonoid & $(+)$ Flavonoid \\
\hline Uji Polifenol & $(+)$ Polifenol \\
\hline Uji Alkaloid & $(+)$ Alkaloid \\
\hline
\end{tabular}


Uji alkaloid pada daun sirih hijau memberikan hasil positif pada penambahan pereaksi bouchardat, mayer dan dragendrof. Pada mayer terjadi endapan menggumpal yang berwarna putih atau kuning, pada bouchardat terbentuk endapan berwarna coklat hingga kehitaman menunjukan hasil yang positif, pada dragendrof terjadi endapan berwarna merah atau jingga (Robinson, 1995). Pada Uji flavonoid ekstrak daun sirih hasil positif jika reduksi dengan magnesium dan asam klorida pekat menghasilkan warna jingga pada lapisan amil alkohol (Robinson, 1995). Uji Tanin saat penambahan pereaksi Fe (III) klorida $1 \%$ memberikan warna hijau kehitaman adanya tannin dengan 3 gugus hidroksil. Menurut (Robinson 1995), senyawa tannin terbentuk kompleks dengan larutan Fe (III) klorida menghasilkan warna hitam, biru sampai warna hijau yang menunjukkan adanya senyawa fenol. Senyawa polifenol seperti tanin dan flavonoid merupakan metabolit sekunder pada tumbuhan memiliki sifat sebagai antibakteri (Harbone, 1987).

\section{Uji Organoleptik}

Tabel 2. Hasil uji organoleptik

\begin{tabular}{ccccc}
\hline Formula & Hari & Warna & Parameter Bau & Kekerasan \\
\hline \multirow{2}{*}{ F0 } & $\mathrm{Ke}-0$ & Putih & Khas Basis & Semi Padat \\
\cline { 2 - 5 } & $\mathrm{Ke}-7$ & Putih & Khas Basis & Semi Padat \\
\hline \multirow{2}{*}{ F1 } & $\mathrm{Ke}-0$ & Kuning Kehijauan & Khas Basis & Semi Padat \\
\cline { 2 - 5 } & $\mathrm{Ke}-7$ & Kuning Kehijauan & Khas Basis & Semi Padat \\
\hline \multirow{2}{*}{ F2 } & $\mathrm{Ke}-0$ & Kuning Kehijauan & Khas Basis & Semi Padat \\
\cline { 2 - 5 } & $\mathrm{Ke}-7$ & Kuning Kehijauan & Khas Basis & Semi Padat \\
\hline \multirow{2}{*}{ F3 } & $\mathrm{Ke}-0$ & Kuning Kehijauan & Khas Basis & Semi Padat \\
\cline { 2 - 5 } & $\mathrm{Ke}-7$ & Kuning Kehijauan & Khas Basis & Semi Padat \\
\hline \multirow{2}{*}{ F4 } & $\mathrm{Ke}-0$ & Kuning Kehijauan & Khas Basis & Semi Padat \\
\cline { 2 - 5 } & $\mathrm{Ke}-7$ & Kuning Kehijauan & Khas Basis & Semi Padat \\
\hline
\end{tabular}

Diperoleh hasil pada saat pengujian organoleptik yaitu pada F0 (blanko) menghasilkan warna putih, bau khas basis, dan bentuk semi padat. Pada F1 (5\%) menghasilkan warna kuning kehijauan, bau khas basis dan bentuk semi padat. Pada F2 (10\%) menghasilkan warna kuning kehijaun, bau khas basis dan bentuk semi padat. Pada F3 (15\%) menghasilkan warna kuning kehijaun, bau khas basis, dan bentuk semi padat. Dan pada F4 (20\%) menghasilkan warna kuning kehijaun, bau khas basis dan bentuk semi padat.

\section{Uji Homogenitas Sediaan}

Tabel 3. Homogenitas sediaan

\begin{tabular}{ccc}
\hline No. & Sediaan & Homogenitas \\
\hline 1 & F0 & Homogen \\
\hline 2 & F1 & Homogen \\
\hline 3 & F2 & Homogen \\
\hline 4 & F3 & Homogen \\
\hline 5 & F4 & Homogen \\
\hline
\end{tabular}

Homogenitas tersebut dilihat dari tersebarnya persamaan warna, tidak terdapat partikel tidak larut dan tidak terdapat gumpalan-gumpalan pada kaca objek. Proses cycling test tidak mempengaruhi homogenitas sediaan gel. Diperoleh hasil pada F0 (blanko) yaitu homogen, Pada F1 (5\%) yaitu homogen, Pada F2 (10\%) homogen, Pada F3 
(15\%) yaitu homogen dan pada F4 (20\%) homogen. Uji ini menjadi salah satu faktor penting untuk mengetahui kualitas suatu sediaan. Tujuan dilakukannya uji homogenitas yaitu untuk mengetahui apakah komponen sediaan tersebut bercampur dengan baik dan tidak mengandung butiran-butiran atau partikel-partikel kasar yang belum terlarut (Shu, 2013).

\section{Uji pH Sediaan Hand Sanitizer}

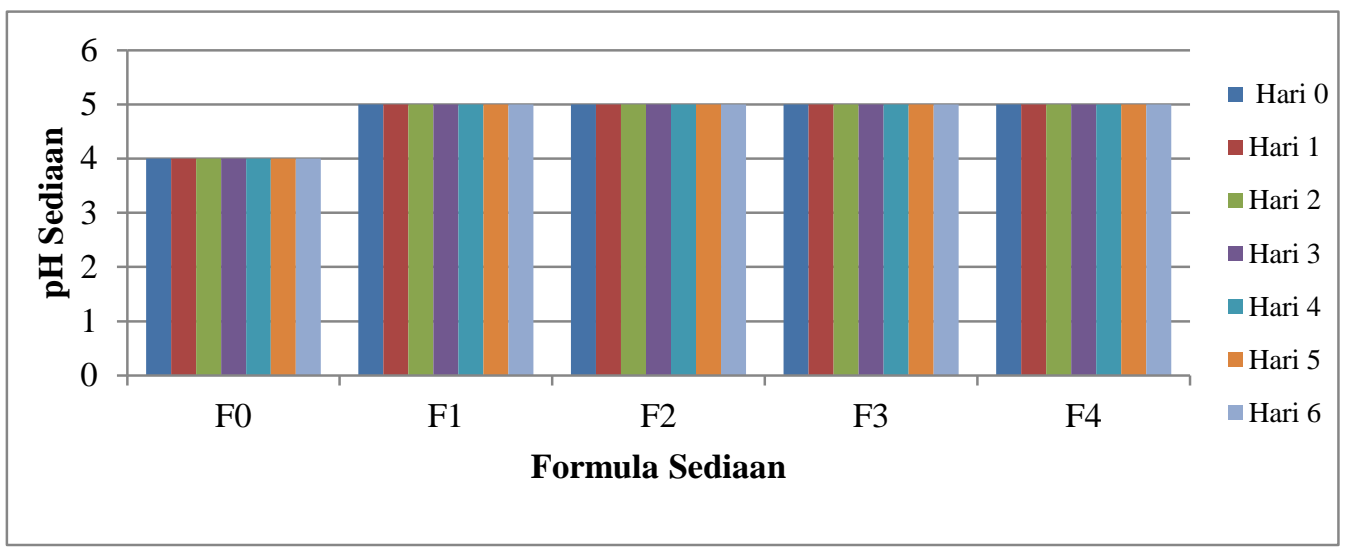

Gambar 1. Hasil uji pH sediaan

Hasil pengukuran $\mathrm{pH}$ selama 1 minggu, menunjukkan hasil $\mathrm{pH}$ sediaan hand sanitizer F0 (blanko), F1 (10\%), F2 (15\%), F3 (15\%) dan F4 (20\%) berkisar antara 4-5. $\mathrm{pH}$ sediaan yang dihasilkan memenuhi batas $\mathrm{pH}$ fisiologis kulit, menurut literature $\mathrm{pH}$ kosmetik diupayakan sama dengan $\mathrm{pH}$ fisiologis kulit yaitu 4,5-6,5 (Tranggono dan Fatma, 2007). Apabila nilai pH terlalu asam bisa menyebabkan terjadinya iritasi kulit dan bila terlalu basa menyebabkan kulit bersisik (Rowe, Dkk 2006).

\section{Uji Daya Sebar}

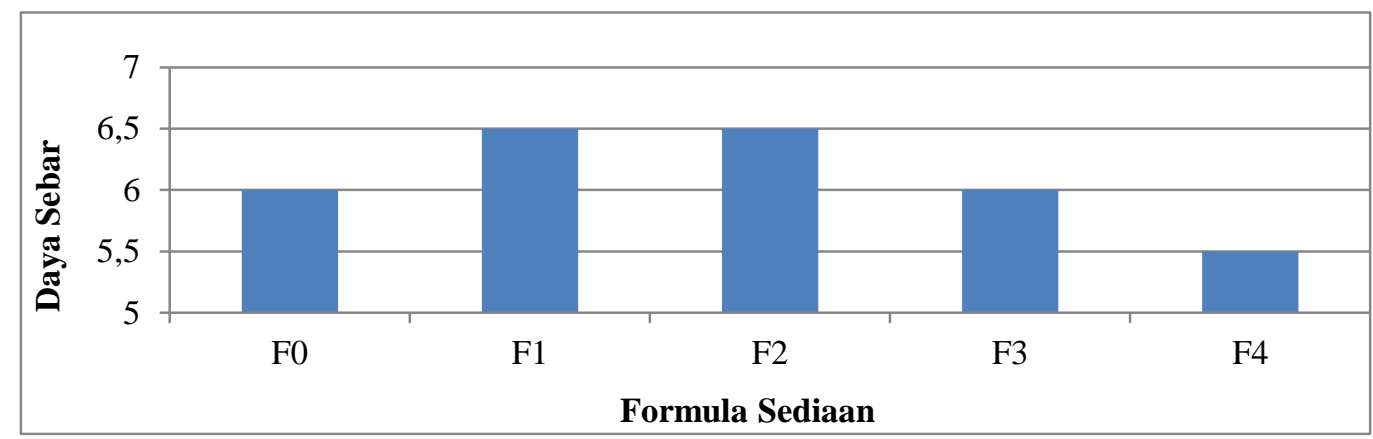

Gambar 2. Hasil uji daya sebar

Hasil daya sebar sediaan gel dikatakan baik yaitu berkisar 5-7 $\mathrm{cm}$ atau 5,54-6, 08 $\mathrm{cm}$ (berdasarkan standar SNI). Semakin besar daya sebar menunjukkan kemampuan zat aktif untuk menyebar dan juga kontak dengan kulit semakin luas. Hasil evaluasi daya sebar yang di dapat yaitu pada F0 (Blanko) yaitu $6 \mathrm{~cm}$, pada F1 $(5 \%)$ yaitu $6,5 \mathrm{~cm}$, pada F3 (15\%) yaitu $6,5 \mathrm{~cm}$ dan pada F4 (20\%) yaitu $5,5 \mathrm{~cm}$. Jadi berdasarkan standar SNI yang sudah dijelaskan diatas, maka uji daya sebar yang terbaik dari penelitian yaitu pada 
F3 dan F4. Karena menurut SNI daya sebar daya sebar yang baik adalah 5-7 $\mathrm{cm}$ atau 5,54-6, $08 \mathrm{~cm}$ (Niyogi, 2012).

\section{Uji Stabilitas Sediaan Gel Hand Sanitizer Ekstrak Daun Sirih Hijau (Piper betle Linn.)}

Tabel 4. Hasil uji organoleptik selama freezer thaw cycling.

\begin{tabular}{ccccc}
\hline Formula & Hari & Warna & Parameter Bau & Kekerasan \\
\hline \multirow{2}{*}{ F0 } & $\mathrm{Ke}-0$ & Putih & Khas Basis & Semi Padat \\
\cline { 2 - 5 } & $\mathrm{Ke}-7$ & Putih & Khas Basis & Semi Padat \\
\hline \multirow{2}{*}{ F1 } & $\mathrm{Ke}-0$ & Kuning Kehijauan & Khas Basis & Semi Padat \\
\cline { 2 - 5 } & $\mathrm{Ke}-7$ & Kuning Kehijauan & Khas Basis & Semi Padat \\
\hline \multirow{2}{*}{ F2 } & $\mathrm{Ke}-0$ & Kuning Kehijauan & Khas Basis & Semi Padat \\
\cline { 2 - 5 } & $\mathrm{Ke}-7$ & Kuning Kehijauan & Khas Basis & Semi Padat \\
\hline \multirow{2}{*}{ F3 } & $\mathrm{Ke}-0$ & Kuning Kehijauan & Khas Basis & Semi Padat \\
\cline { 2 - 5 } & $\mathrm{Ke}-7$ & Kuning Kehijauan & Khas Basis & Semi Padat \\
\hline \multirow{2}{*}{ F4 } & $\mathrm{Ke}-0$ & Kuning Kehijauan & Khas Basis & Semi Padat \\
\cline { 2 - 5 } & $\mathrm{Ke}-7$ & Kuning Kehijauan & Khas Basis & Semi Padat
\end{tabular}

Untuk uji stabilitas dilihat dari hasil uji pengamatan organoleptis, uji homogenitas dan uji $\mathrm{pH}$ maupun uji sifat fisik lainnya, menunjukkan sediaan gel hand sanitizer ekstrak etanol daun sirih tidak ada perubahan yang berarti (stabil) dan tidak adanya pemisahan fase pada sediaan gel hand sanitizer. Uji stabiitas dengan metode freezer thaw cycling dilakukan untuk mengetahui apakah sediaan mengalami pemisahan fase setelah proses penyimpanan (Shu, 2013).

\section{Uji Iritasi Sediaan Gel Hand Sanitizer}

Tabel 5. Uji iritasi sediaan

\begin{tabular}{|c|c|c|c|c|c|c|c|c|c|c|c|c|c|}
\hline \multirow[b]{2}{*}{$\begin{array}{l}\mathbf{N} \\
\mathbf{0}\end{array}$} & \multirow[b]{2}{*}{$\begin{array}{c}\text { Formu } \\
\text { la }\end{array}$} & \multicolumn{12}{|c|}{ Uji Iritasi (+/-) } \\
\hline & & P-1 & P-2 & P-3 & P-4 & P-5 & P-6 & P-7 & P-8 & P-9 & $\begin{array}{l}\text { P. } \\
10\end{array}$ & $\begin{array}{l}\text { P- } \\
11\end{array}$ & $\begin{array}{l}\text { P- } \\
12\end{array}$ \\
\hline 1. & F0 & - & - & - & - & - & - & - & - & - & - & - & - \\
\hline 2. & F1 & - & - & - & - & - & - & - & - & - & - & - & - \\
\hline 3. & $\mathrm{~F} 2$ & - & - & - & - & - & - & - & - & - & - & - & - \\
\hline 4. & F3 & - & - & - & - & - & - & - & - & - & - & - & - \\
\hline 5. & $\mathrm{~F} 4$ & - & - & - & - & - & - & - & - & - & - & - & - \\
\hline
\end{tabular}

Pengujian iritasi sediaan gel hand sanitizer dibuat untuk mengetahui keamanan sediaan karena penggunaannya secara topikal. Pengujiaan dilakukan dengan cara mengaplikasikan sediaan di belakang telinga panelis dan dilihat efek yang terjadi. Berdasarkan hasil pengujian terhadap 12 orang panelis menunjukkan tidak adanya iritasi yang terjadi pada bagian belakang telinga seperti kemerahan pada kulit, gatal dan kulit menjadi kasar.

\section{KESIMPULAN}

Ekstrak etanol daun sirih hijau (Piper betle Linn.) dapat diformulasikan ke dalam sediaan gel hand sanitizer. Uji organoleptik pada sediaan diperoleh pada semua F0 
memiliki warna putih sedangkan pada formula 1 sampai 4 memiliki warna kuning kehijauan, pada uji homogenitas diperoleh hasil homogen untuk semua formula, pada uji $\mathrm{pH}$ diperoleh nilai $\mathrm{pH}$ berkisar antara 4-5, pada uji daya sebardiperoleh hasil pada $\mathrm{F} 0$ (Blanko) yaitu $6 \mathrm{~cm}$, pada F1 (5\%) yaitu $6,5 \mathrm{~cm}$, pada F3 (15\%) yaitu $6,5 \mathrm{~cm}$ dan pada F4 (20\%) yaitu $5,5 \mathrm{~cm}$, untuk uji stabilitas yaitu stabil, untuk uji iritasi yaitu tidak menyebabkan iritasi pada kulit.

\section{REFERENSI}

Depkes RI. 1995. “Materia Medika Indonesia. Jilid Keenam”. Jakarta: Direktorat Jendral Pengawasan Obat dan Makanan. Halaman 300, 302-304, 306, 334, 540, 536.

Depkes RI. 2000. "Parameter Standar Umum Ekstrak Tanaman". Jakarta: Departemen Kesehatan Republik Indonesia. Halaman 9-12.

Harbone, J.B. 1987. "Metode Fitokimia Edisi Kedua". ITB. Bandung.

Hurria. 2014. "Formulasi, Uji Stabilitas Fisik, Dan Uji Aktifitas Sediaan Gel Hand Sanitizer Dari Air Perasan Jeruk Nipis (Citrus aurantifolia Swingle) Berbasis Karbomer". Jurnal Farmasi Fik Uinam. Vol.2 No (1) Hal : 28-33.

Marliana, S.D., V. Suryanti., Suyono. 2005. "Skrining Fitokimia dan Analisis Kromatografi Lapis Tipis Komponen Kimia Buah Labu Siam (Sechium edule Jacq. Swartz.) dalam Ekstrak Etanol. Biofarmasi”. 3(1): 26-31.

Moeljanto, R.D., Mulyono. 2003. "Khasiat dan Manfaat Daun Sirih, Obat Mujarab dari Masa ke masa". Agromedia Pustaka Hal: 7-11, Yogyakarta.

Niyogi, Nurkalis. 2012."Ekstraksi Nikotin Dari Daun Tembakau (Nicotina tabacum) dan Pemanfaatannya Sebagai Insektisida Nabati Pembunuh Aedes SP. Jurnal Ilmiah Mahasiswa". 2 (2). 67-70.

Radji, Maksum. 2010. "Buku Ajar Mikrobiologi Panduan Mahasiswa Farmasi dan Kedokteran". Jakarta: EGC. Hal:180-190

Robinson, T. 1995. "Kandungan Organik Tumbuhan Tinggi. Edisi VI. Halaman 191-198. Diterjemahkan oleh Kosasih Padmawinata. ITB. Bandung".

Rowe, R.C. Sheskey, P.J. Quinn M.E. 2006. Handbook Pharmaceutical.

Shu, M. 2013. "Formulasi Sediaan Gel Hand Sanitizer Dengan Bahan Aktif Triklosan 0,5 \% dan $1 \%$ ". Jurnal Ilmiah Mahasiswa. Universitas Surabaya. Vol.2 No.1.

Tranggono., Relswari, Fatma Latifah. 2007. "Buku Pegangan Ilmu Pengetahuan Kosmetik". Jakarta : PT. Gramedia Pustaka Utama; Halaman 183. 